\title{
Bacteriological monitoring of ships' ballast water in Singapore and its potential importance for the management of coastal ecosystems
}

\author{
V. Ivanov \\ Maritime Research Centre, School of Civil and Environmental \\ Engineering, Nanyang Technological University, Singapore
}

\begin{abstract}
The bacteriological quality of ships' ballast water was studied to evaluate the risk of invasion by alien bacterial species in Singapore. Guidelines of the International Maritime Organization (IMO) are currently in place concerning the threat posed by invasive pathogens due to uncontrolled discharge of ballast water and sediment from ships. The bacteriological quality of ship's ballast water was studied to evaluate the risk of invasion by alien bacterial species in Singapore. The concentrations of total bacteria, enterobacteria, Vibrio spp., and Escherichia coli have been compared for ballast water samples taken from ships in Singapore Harbour. The share of facultative-anaerobic bacteria, which are often the agents of water-borne diseases, in a ship's ballast water was usually higher than in seawater, especially for the cases when the ballast water tank was filled to the top. Samples of ballast water contained from 0.7 to $39.5 \%$ of eubacteria, 0 to $2.5 \%$ of enterobacteria, 0.2 to $35.8 \%$ of Vibrio spp., and from 0 to $2.5 \%$ of $E$. coli. The significant percentage of Vibrio spp. in some samples of ballast water shows possibly increased risk of invasion of microbial pathogens as ballast water will be discharged in coastal area. Simple self-manufactured chromogenic test kit for coliforms in water showed semi-quantitatively the level of faecal pollution in water. The regular monitoring of ballast water for selected microbial pathogens must be performed continuously for reliable conclusions. Disinfection of ballast water, discharged in the coastal area of Singapore, can be recommended as mandatory treatment if some microbial pathogens are frequently detected in the ship's ballast water.
\end{abstract}

Keywords: ballast water, bacteriological monitoring, coliforms, Vibrio sp. 


\section{Introduction}

Microbiological monitoring of discharged in the port or coastal area ships' ballast water could diminish the risk of invasive species of microorganisms and microbial water-borne infectious diseases, It is also can be used to verify quality of discharged ballast water treatment/disinfection. Risk of invasion by microbial pathogens due to discharge of ballast water in coastal area is evaluated using the regulation D-2 of International Convention for the Control and Management of Ships Ballast Water \& Sediments which was adopted by consensus at a Diplomatic Conference at IMO in London on Friday 13 February 2004. The indicator microbes but are not be limited to: (a) toxicogenic Vibrio cholerae (O1 and O139) with less than 1 colony forming unit (cfu) per 100 milliliters or less than 1 cfu per 1 gram (wet weight) zooplankton samples; (b) Escherichia coli less than 250 cfu per 100 milliliters; (c) intestinal enterococci less than $100 \mathrm{cfu}$ per 100 milliliters. The conventional methods are often not appropriate for the analysis of ballast water. For practical ballast water analysis, new methods have been developed for simple monitoring of bacteriological quality of water. These methods are able to provide rapid results, be easily performed by an analyst with little or no microbiological training, and give an accurate enumeration of harmful microorganisms. Some commercial probe assay kits for the rapid detection and enumeration of the indicator bacteria $E$. coli are known but all existing standards for microbiological water quality are still based on cultivation methods.

Flow cytometry is a useful tool for assessing many parameters of microorganisms including enumeration, viability, and identification. Fluorescence in situ hybridization (FISH) methods with oligonucleotide probes (matched to the genetic sequences of particular organisms) are useful for the identification of individual microbial cells by flow cytometry. Specific oligonucleotide probes for the detection of Escherichia coli, Vibrio, dinoflagellate algae producing paralytic shellfish toxins, marine nanoplanktonic protists, photosynthetic eukaryotic microorganisms, marine nanoflagellates, marine cyanobacteria, and other indicator or pathogenic microorganisms may be used for monitoring the microbiological quality of a ship's ballast water.

The aim of this research was to develop simple and rapid methods of detecting microbes in discharged ballast water that are applicable to the monitoring of ballast water treatment quality in ships. The applicability of a flow cytometry-based method has been currently under examination for ballast water quality monitoring involving the enumeration and identification of microorganisms.

\section{Methods}

Methods of the sampling and analysis of ballast water by conventional microbiological approaches and by flow cytometry combined with molecular probes have been described earlier (Tay et al. [5]; Joachimsthal et al. [2-4]). 


\section{Results}

Total concentration of bacteria in ballast water varied significantly, from 30 to 2100 thousand cells/mL. It shows variability of bacterial pollution of ballast water (Table 1).

Table 1: $\quad$ Variability of bacterial numbers in the samples of ballast water.

\begin{tabular}{ccc}
\hline Sample & Target bacteria & $\begin{array}{c}\text { Concentration of specifically } \\
\text { stained cells (cells/mL) }\end{array}$ \\
\hline Ballast 1 & Eubacteria & $2100 \times 10^{3}$ \\
\hline Ballast 2 & Eubacteria & $50 \times 10^{3}$ \\
\hline Ballast 3 & Eubacteria & $2300 \times 10^{3}$ \\
\hline Ballast 4 & Eubacteria & $1400 \times 10^{3}$ \\
\hline Ballast 5 & Eubacteria & $69 \times 10^{3}$ \\
\hline Ballast 6 & Eubacteria & $30 \times 10^{3}$ \\
\hline
\end{tabular}

It was a reliable correlation between the number of particles with size from 1 to $4 \mu \mathrm{m}$ (determined by portable particle counter) and the number of bacterial cells (determined by flow cytometer). Therefore, concentration of bacterial cells in ballast water can be determined in the port laboratory or even on board by portable particle counter. However, it cannot differentiate dead and viable bacterial cells in the sample.

The majority of microorganisms in the seawater samples were either obligate aerobes or microaerophilic. For the ballast water, the proportion of aerobic microorganisms was $11 \%$. However, the proportion of facultative anaerobic microorganisms increased, from $7 \%$ in the seawater samples, up to $50 \%$ in the ballast water samples. Domination of facultative anaerobes increases the risk of transfer of water-borne diseases.

The number of enterobacteria in ballast water samples varied from 0 to 15 thousand cells $/ \mathrm{mL}$. It shows high risk of water borne-diseases in some samples of ballast water (Table 2). Because of high variability of enterobacteria, E. coli and Vibrio spp. cell numbers, which are indicators of faecal pollution of ballast water and risk of water-borne disease due to the discharge of ballast water, cells with $\beta$-galactosidase activity can be detected as an indicator of ballast water pollution. 
Table 2: Variability of enterobacterial numbers in the samples of ballast water.

\begin{tabular}{ccc}
\hline Sample & Target bacteria & $\begin{array}{c}\text { Concentration of specifically } \\
\text { stained cells (cells } / \mathrm{mL})\end{array}$ \\
\hline \hline Ballast 1 & Enterobacteria & $15 \times 10^{3}$ \\
\hline Ballast 2 & Enterobacteria & $11 \times 10^{3}$ \\
\hline \hline Ballast 3 & Enterobacteria & $14 \times 10^{3}$ \\
\hline Ballast 4 & Enterobacteria & 0 \\
Ballast 5 & Enterobacteria & $14 \times 10^{3}$ \\
\hline \hline Ballast 6 & Enterobacteria & 0 \\
\hline
\end{tabular}

\section{Conclusions}

The number of coliforms in almost all samples of ballast water taken in Singapore exceeded the values of regulation D-2 of International Convention for the Control and Management of Ships Ballast Water \& Sediments. Therefore, the disinfection of ballast water discharged in the port or coastal area of Singapore can be recommended for the cases when the regulation D-1 (ballast water exchange shall do so with an efficiency of $95 \%$ volumetric exchange of ballast water or by the pumping through three times the volume of each ballast water tank) was not performed. In this case, instead of measurement does ships' ballast water exceed IMO-recommended levels, the detection of alive bacterial cells in ballast water must be performed using fast and simple specially designed immunochemical test kits to evaluate efficiency of ballast water disinfection on the ships discharging ballast water in the port or coastal area.

\section{References}

[1] Ivanov V., Joachimsthal E.L., S.T.L. Tay and J.H. Tay. (2004) Bacteriological quality of ship's ballast water. Singapore Maritime and Port Journal: $101-108$.

[2] Joachimsthal E. L., V. Ivanov, J.-H. Tay, S.T.-L. Tay (2002). Flow cytometry and conventional enumeration of microorganisms in ships ballast water and marine samples. Marine Pollution Bulletin, 46 (3): 308 - 313. 
[3] Joachimsthal E. L., V. Ivanov, J.-H. Tay, S.T.-L. Tay (2003). Quantification of whole-cell in situ hybridization with oligonucleotide probes by flow cytometry of Escherichia coli cells. World Journal of Microbiology and Biotechnology, 19 (5): 527-533.

[4] Joachimsthal E.L., V. Ivanov, S.T.L. Tay and J.H. Tay. (2004) Bacteriological examination of ballast water in Singapore harbour by flow cytometry with FISH. Marine Pollution Bulletin, 49(4): 334- 343.

[5] Tay Joo Hwa, Volodymyr Ivanov, Xiaoge Chen, Eva L. Joachimsthal, Maszenan Bin Abdul Majid, and Stephen Tiong Lee Tay. (2002) Monitoring of bacteriological quality of ballast water in Singapore by flow cytometry. Singapore Maritime \& Port Journal: 87-99. 